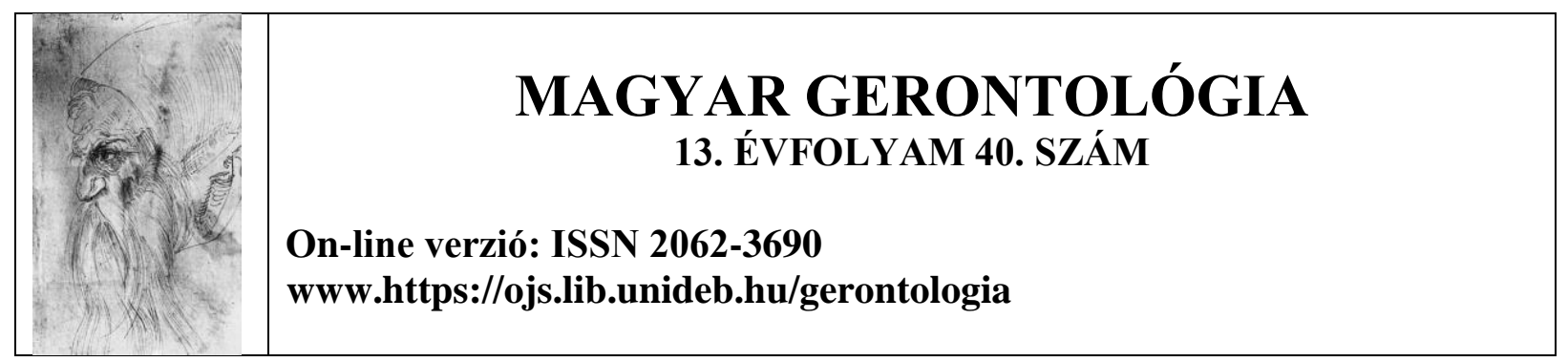

\title{
AZ IDŐSEK ÉS AZ INFOKOMMUNIKÁCIÓS TECHNOLÓGIÁK ELSŐDLEGES VONATKOZÁSAI
}

\section{Kristóf Zsolt, Győri Anita}

Debreceni Egyetem Egészségügyi Kar

Kulcsszavak: idősek, infokommunikációs technológiák, életminőség

\begin{abstract}
Absztrakt
Cikkünkben kitérünk az információs és kommunikációs technológia (továbbiakban IKT) rövid áttekintésére, az idős korosztály legjellemzőbb sajátosságaira, végül azt vizsgáljuk, hogyan és mely részterületeken tudnak kapcsolódni az idősek az IKT megoldásaihoz. A gyorsan fejlődő technológia világában még azoknak sem könnyü kiigazodni, akiknek nem kell gondolkozni azon, hogy hogyan tanulják meg az IKT használatát. Komoly hátránnyal indulnak azok, akik életük egyharmadában, felében nem voltak kapcsolatban az infokommunikációs technológiákkal, idős korban pedig ez a hátrány tovább növekedhet. Manapság egyre nehezebb különbséget tenni online és offline világ között és valószínüleg ez a jövőben sem lesz könnyebb. A jóléti államokat elöregedő társadalom jellemzi, az ezekből fakadó problémák régóta jelen vannak minden területen, ahogy az egészségügyben, úgy a gazdaságban is. Tanulmányunkban megvizsgáljuk és összegyüjtjük a témakörhöz szorosan kapcsolódó releváns szakirodalmakat, melyek az életminőségre, a magányosság leküzdésére, a társadalmi felzárkóztatásra és az egyén egészségi állapotára vonatkoznak. Célunk, hogy megvizsgáljuk milyen lehetőségekkel segíti az IKT az idős emberek minőségi öregedését, milyen tényezők motiválják az időseket az eszközök használatában, melyek azok a nehézségek, amelyek akadályozzák az alkalmazást és a tanulást, illetve, hogy összességében milyen jövőbeni kilátások elé nézünk. Vizsgálatunk angol és
\end{abstract}


magyar nyelvű szakirodalomra vonatkozott, azokra a publikációkra, melyek Európában jelentek meg vagy európai országokban végezték a kutatást, a 65 éves vagy idősebb emberek körében, 2011 és 2021 között.

\title{
PRIMARY ASPECTS OF THE ELDERLY AND INFORMATION COMMUNICATION TECHNOLOGIES
}

\author{
Zsolt Kristóf, Anita Győri
}

Keywords: the elderly, information and communication technology, quality of life

\begin{abstract}
In this article, we will briefly review information and communication technology (ICT), the most typical characteristics of the elderly age group, and finally, we will look at how and in which areas the elderly can connect to ICT solutions. It is not easy to navigate in a world of rapidly evolving technology even for those who do not have to think about how to learn using ICT. In a rapidly evolving world of technology, it is not easy for those who does not need to think about how to learn how to use ICT to adapt. Those who have not been in touch with ICT for a third or half of their lives start from a serious disadvantage, and this disadvantage can increase in old age. Today it is increasingly difficult to distinguish between the online and offline worlds, and this is unlikely to become easier in the future. Welfare states are characterized by an aging society, and the resulting problems have long been present in all areas, from health to economy. In our study we will examine and bring together relevant literature closely related to this topic, covering quality of life, overcoming loneliness, social inclusion and the health of the individual. Our aim is to explore the potential of ICT for quality ageing of older people, the factors that motivate them to use the tools, the difficulties that hinder their use and learning, and the future prospects. Our study covered the English and Hungarian language literature, publications published in Europe or research conducted in European countries, among people aged 65 and over, between 2011 and 2021.
\end{abstract}




\section{Bevezetés}

Az idősek infokommunikációs technológiákkal történő interakciója pozitívan befolyásolhatja szellemi tevékenységüket és összességében jó hatással lehet a mentális egészségük serkentésére. Ez a mentális stimuláció javíthatja a memóriájukat is. Az IKT-t használó idősek úgy érzik, sokkal magabiztosabbak és kevésbé vannak elszigetelve a társadalomtól, megnöveltnek látják a társadalmi támogatást és társadalmi interakciót, jobb kognitív képességekkel rendelkeznek, fennmaradhat a függetlenség érzése a mindennapi életükben és körükben alacsonyabb szintü depressziót mérnek a kutatók. Az IKT-t megfelelő szinten alkalmazó személyek kiemelten hasznos tagjai lehetnek közösségüknek, mivel képesek átadni bölcsességüket és tudásukat a fiatalabb generációknak a fejlett technológián keresztül is. A digitális technológiákat értően használó idős személy és a fiatalabb generációk közötti digitális szakadék elmosódottabbá válhat. Ezzel együtt javulhat az érintettek személyes életminősége, a függetlenség és autonómia fenntartása a mobilitást is fokozza, kialakulhat és müködhet a személyre szabott integrált szociális és egészségügyi ellátáshoz való hozzáférés. Kijelenthető, hogy a digitális kompetenciák színvonalas alkalmazása összességében pozitívan tud hatni az idősek saját életére és a hozzájuk tartozókéra is (Blazun, 2013).

Jelenleg - főleg az elmúlt évtizedekhez képest - a kifejezetten idősebbek számára készült technológiai eszközök és megoldások felé mutatott igény, ennek következtében pedig ezek piacképessége is fellendülésben van. A gerontechnológia - melynek területéhez tartozik minden olyan okos szolgáltatás és technikai innováció, amely az idősek életminőségét javíthatja - segíthet a minőségi öregedésben és az önálló élet fenntartásában. A kapcsolati szolgáltatások erősíthetik a szocializációt és csökkenthetik az esetleges ellátási költségeket (Peterson \& Prasad, 2011).

Amikor az idősek az IKT lehetőségeket használják, számos kedvező hatással találkozhatnak. Digitális tudásuk fejlődésével csökkenhet a kirekesztődésük, ezzel együtt a magány érzete is, egészségi állapotuk folyamatos monitorozásával lassítható az egészségromlás, addig ismeretlen, új információkhoz tudnak hozzájutni, mely által fenntarthatják vagy növelhetik a mentális kondíciójukat. Kialakíthatják és menedzselhetik a családi és baráti kapcsolattartást, távolabb élő személyekkel tudják felvenni a kapcsolatot, illetve, ha mindezekben fiatalabb családtagjaik segítik őket, szorosabb családi köteléket és intergenerációs hasznot is hoz a folyamat (Bene és mtsai, 2020). Figyelmet kell fordítani arra ugyanakkor, hogy a pozitív tényezők mellett megjelenhetnek a negatív vonatkozások is. Ezek magában foglalhatják azokat az érzéseket, amelyek a személyes kontaktus hiánya miatt 
keletkeznek, olyan egészségi hatások erősödhetnek, mint a szem terhelése, a hosszabb ideig tartó ülés miatt rosszabbodó testtartás, internetes visszaélések célpontjai lehetnek az idősek, esetleg felmerülhet körükben is internet-és okoseszköz függőség.

Cikkünkben azt vizsgáljuk, hogy az IKT hogyan segítheti az idősek mindennapjait a tanulás, a magányosság az egészségügy és egyéb, általánosabb területek vonatkozásában.

\section{Az infokommunikációs technológia és alkalmazásai}

Az információs és kommunikációs technológiára (IKT) nincs általános, mindenki által ismert és elismert definíció. Minden olyan digitális eszköz ebbe a meghatározásba tartozik, amely ötvözi az informatikát és a távközlést. Ezek az eszközök lehetővé teszik az információ tárolását, hozzáférhetőségét, kezelését, illetve továbbítását. IKT-t használunk, ha tv-t nézünk, videót készítünk, telefonálunk, közösségi oldalakon vagyunk jelen, interneten vásárolunk vagy akár autónkban, akár egyéb okoseszközünkön bekapcsoljuk a GPS-t. Az IKT magját szoftverek, hardverek, hálózatok és médiumok alkotják, amelyek elsősorban információgyűjtésre, bemutatásra, feldolgozására, tárolására és továbbítására szolgálnak hangon, szövegen és képeken keresztül (Al-Rahmi és mtsai, 2020).

A 21. századra az élet egészét átható és állandóan elérhető technológia jelentős mértékben átalakította az emberek életét. Dolgozunk, kommunikálunk, ügyeinket intézzük, problémákat oldunk meg és ismereteket szerzünk a segítségével. Megváltoztatta az emberek szokásait, szórakozását, kapcsolattartási és vásárlási módjait, az információteremtés módszerét, és mindezekkel összefüggően a munka természetét is (Molnár, 2011). Létrejöttek a „digitális bennszülött” és „digitális bevándorló” fogalmak, melyekkel megpróbálták kifejezni napjaink társadalmának IKT hozzáértés alapján vett különbségeit (Prensky, 2001). Prensky aszerint különböztette meg a két csoportot, hogy tagjaik mikor találkoztak a technológiával. Digitális bennszülöttként tekintett azokra a fiatalokra, akik számára már természetessé vált az IKT mindennapos használata, a digitális bevándorlók pedig azok voltak, akik felnőtt korukban találkoztak a digitális eszközökkel és aktívan kellett tanulniuk a használatukat. Mivel egyre inkább elmosódnak ezek a határok később Prensky maga javasolt egy új kifejezést, a „digitális bölcsességet”, mely már nem képez korosztályon alapuló különbséget, sokkal inkább egyfajta digitális technológia készséget jelöl (Prensky, 2009). Ehhez kapcsolódóan találkozhatunk a szakirodalomban a „digitális szakadék” kifejezéssel, mely szintén a nemzedékek közötti különbséget szemlélteti, ám a 2001-ben leírtaktól tágabb módon. Nemcsak demográfiai értelemben kerül használatra, hiszen földrajzi vagy társadalmi csoportok közötti különbségekre 
is alkalmazható (Fehérvári, 2017). A digitális szakadék fogalmával egyidős az információs társadalom fogalma is, mely egy olyan, új jellegü társadalmat takar, amelyben az információs és telekommunikációs technológiák széles körü elterjedésével az adott társadalom tagjainak jobb minőségü életre, ezzel együtt új típusú életvitelre, modernebb munkavégzésre van lehetősége. A fentiekkel a társadalomban betöltött megváltozott szerep is együtt jár (Z. Karvalics, 2001).

Az információs és kommunikációs technológia alkalmazási lehetőségeit a 2019-ben megjelent Covid-19 vírus miatt kihirdetett veszélyhelyzet szükségszerüen előtérbe helyezte. Még inkább felerősödött az igény az információ gyors áramlására, a naprakészségre, a kapcsolattartásra, szociális igényeink kielégítésére, a digitális lehetőségeink megismerésére.

A kutatások eredményei szerint a fiatalok, a gyermekek voltak védettebbek a megbetegedés súlyos vagy akár halálos kimenetelétől, ugyanakkor akár kisebb tünetek mellett vagy tünetek nélkül is terjeszthették a betegséget. A fentieket alátámasztották további kutatások, melyek eredményei azt mutatták, hogy a fertőzött személyekkel történő hosszabb időn át tartó érintkezés - akár csak az egy légtérben tartózkodás - lehetett a vírus terjedésének legvalószínűbb módja. Járványok idején a kockázatcsökkentő stratégiák, például a társadalmi távolságtartás a vírusok terjedését nemcsak a sűrün látogatott iskolákban tudja lassítani, hanem bármilyen egyéb közösségben is (Kristóf, 2020). Az egészségügyi kockázat megnövekedett szintje, a szociális távolságtartás komolysága és kötelezősége mindenkire hatással volt. Nagyon gyorsan kellett elsajátítanunk egy új világ normáit, melyben a digitális eszközök széles körü alkalmazása mindennapi elvárássá emelkedett.

Egy magyarországi interjú alapú kutatás alapján általában elmondható, hogy a karantén idején az idősekkel foglalkozó szervezetek fokozottabban figyelték tagjaikat, igyekeztek fenntartani a kapcsolatot mindenkivel és többnyire az új infokommunikációs technológiát használva, összekötötték a tagságot egymással. A kapcsolattartás a tagok közötti információáramláson túl a szabadidős tevékenységekről szólt, amelyekben számos innovatív ötlet valósult meg. Az idősekre az összetartás és az egymásra való odafigyelés volt jellemző. A kutatók leginkább azok esetében fogalmaztak meg problémákat, akik nagyvárosokban, lakótelepeken, erkély nélküli lakásokban élték meg a karantént. Az interjúalanyok meglátása és tapasztalatai szerint a vidékiek, illetve a kerttel, udvarral rendelkezők mentálisan könnyebben vészelték át a korlátozásokat. Általános tapasztalat, hogy az idősek betartották a szabályokat, viselték a maszkot, kesztyüt, bár a vásárlási korlátozást nehezebben fogadták. A válaszadók között legtöbben azt fogalmazták meg, hogy a gyerekekkel, főleg az unokákkal, dédunokákkal való kapcsolat hiányzott nagyon (Huszti és mtsai, 2020). 


\section{Az időskori ageizmus és a minőségi öregedés}

Az öregkor ma jogi meghatározás kérdése abban az értelemben, hogy arra az életkorra vonatkozik, amikor az emberek visszavonulnak a munkától, és olyan sajátos jóléti szolgáltatásokra tarthatnak igényt, mint a nyugdíj. Magyarországon a nyugdíjkorhatár 65 év, cikkünkben az időskor a 65 év felettiekre vonatkozik.

A nyugdíjazás elemi változásokat hoz a nyugdíjba vonuló személy és családja életébe. Lecsökken a jövedelem, fokozatosan leépülnek a munkahelyi, baráti kapcsolatok, a felszabadult időt a legtöbb friss nyugdíjas nem mindig tudja optimálisan kezelni. Sokszor feleslegesnek érzik magukat, ami mentális problémákat okozhat. Egy olyan társadalomban, ahol a munka centrális érték, a nyugdíjazás státuszvesztéssel is jár és az évek során összegyüjtött tudás és szakértelem már nem kelt tiszteletet a fiatalabb generációkban. Ezek mellett az öregségi vagy az özvegységi nyugdíj, a házastárs halála után egyre kevésbé fedezi a létfenntartást, mely időskori szegénységhez is vezethet (Giddens, 2008). Ilyen élethelyzetekben fontos és szükségessé válik a kiemelt figyelem. A társas támogató hálózat hiánya szorosan kapcsolódik a vélt, és hosszú távon a valós egészségi állapottal. Azok, akiknek a szociális kötelékeik beszükülnek, nagyobb eséllyel mutatnak depresszív tüneteket, válnak szomorúvá vagy számolnak be a feleslegesség érzéséről. Ezek az érzések meghatározzák általános közérzetüket, megelégedésüket. Mindezek az idős korosztálynál fokozottabban jelentkeznek, ezért a társas szabadidő-eltöltésüket egyfajta védőfaktorként foghatjuk fel. Ez kiemelten érinti a bentlakásos idősek intézményének lakóit, akik gyakran valamilyen nehezített életkörülmény, betegség vagy haláleset miatt határoznak az idősek otthona mellett (R. Fedor és mtsai, 2021).

Az ENSZ Egészséges Öregedés Évtizede (2021-2030) egy globális együttmüködés, amely összhangban van a Fenntartható Fejlődési Célok elmúlt tíz évével, és amely egyesíti a kormányokat, a civil társadalmat, a nemzetközi ügynökségeket, a szakembereket, a tudományos szférát, a médiát és a magánszférát, az idősek, családjaik és a közösségeik életének javítása érdekében. A világ népessége egyre gyorsabb ütemben öregszik és ez a demográfiai átalakulás a társadalom szinte minden területére hatással lesz. Már most is több mint 1 milliárd 60 éves vagy annál idősebb ember él, többségük alacsony és közepes jövedelmű országokban. Sokan még azokhoz az alapvető erőforrásokhoz sem férnek hozzá, amelyek az értelmes és méltó élethez szükségesek. Sokan olyan korlátokkal szembesülnek, amelyek megakadályozzák teljes körü részvételüket a társadalomban. A nyugdíjas kor eljövetelével általában a gazdasági aktivitás csökken, az egészségi állapot romlik, de azokon a területeken is beszükülés tapasztalható, amelyek egyénileg is irányíthatók. A barátok átlagos számának csökkenése idős 
korra észrevehető. Megjegyzendő, hogy például a külső kapcsolatok beszüküléséröl egyes esetekben maga az idősebb személy is tehet. Ezzel kapcsolatosan a manapság erősödő, a középfokú oktatásban kötelezővé tett önkéntes munka egy hatékony megoldás lehet a fiatalok idősebb korosztályokkal való kapcsolattartásának fokozására, növelésére (Takács \& Fábián, 2014).

Az idős korosztály egyre növekvő aránya miatt a velük szembeni diszkrimináció is növekszik, melyhez egy új, modern fogalom is társul, az ageizmus. A fogalom az angol age szóból ered, ami kort jelent, tehát az ageizmus az életkor alapján gyakorolt hátrányos megkülönböztetést jelenti. A fogalomból eredően alapvetően nemcsak idősekre vonatkozott a megkülönböztetés. Napjainkban mégis az idősebb korosztállyal szemben megnyilvánuló elöítéletekkel kapcsolatosan használják. Maga a fogalom azért került kialakításra, mert az időskor az elmúlt évtizedekben lényegesen hosszabbá vált, melynek következtében egyre több idős szeretne tevékenyen, aktívan élni, viszont a társadalom ezt legtöbbször nehezen vagy alig tudja kielégíteni. Sajnos sokszor még ma is eltartott, idősotthonban élő, gondoskodásra szoruló személyekként gondolunk az idősekre (Kokas \& Lakatos, 2013).

Az idősek hátrányos megkülönböztetése a következő formákban nyilvánulhatnak meg:

- Nyelvi megkülönböztetésbe tartoznak azok a szavak, kifejezések, melyeket a fiatalabb generáció idegen nyelvekből vett át (pl. meeting, chat, online, stb.) vagy a generációi rétegnyelvekhez tartozik (pl. csaj, zsír, stb.), de az idősebb korosztály nem ismeri, nem használja és nem érti. Emellett a nyelvi diszkrimináció része az is, hogy a fiatalabb korosztály, illetve a társadalom és a média sincs mindig tekintettel az idősebb korosztály lassabb beszédtempójára és beszédértésére.

- A lakóhelyi megkülönböztetés megnyilvánulhat abban, hogy megszünnek azok a közösségi terek, parkok, ahol az idősebb korosztály is jól érezhetné magát, kikapcsolódhatna és biztonságban érezné magát.

- A családon belüli diszkrimináció leggyakoribb esete, hogy idős rokonukat elhanyagolják a családtagok, nem veszik meg a gyógyszereiket, esetleg bántalmazzák őket, elveszik a nyugdíjukat, megtakarított pénzüket. Ezek az esetek csak ritkán derülnek ki, mert az idősekben gyakran is nem tudatosul, hogy rosszul bánnak velük, esetleg félnek a bántalmazóiktól.

- A mediális diszkrimináció a tömegkommunikációban van jelen. A médiában az idősek ritkán szerepelnek, ha szerepelnek is, gyakran erőteljesen lealacsonyító, diszkriminatív helyzetben (pl. vizelettartási problémák, feledékenység, müfogsor használat). Kevés olyan műsor van, amely kifejezetten az idős korosztályt szólítaná meg. Ebbe a megkülönböztetési 
formába tartozik az informatikai jártasság hiánya is. Az idősebb korosztály nagyrészt nem ismeri és nem tudja használni a számítógépet, okostelefonokat. Mindemellett az internethasználat sem épült be a mindennapjaik rutinjába, így naprakész információkkal sem rendelkeznek.

- A gazdasági diszkriminációhoz soroljuk az idősebbek jóindulatát, hiszékenységét kiaknázó házaló kereskedőket, csalókat, akik könnyen becsapják, átverik őket. Jellemzően egészségügyi termékek eladásával és a kivételes ajánlat csábításával próbálják becsapni őket (Balázs \& Bene, 2019). Ebbe a kategóriába tartozik annak ténye is, hogy az idősebbek nem, vagy csak sokkal szigorúbb feltételekkel vehetnek fel hitelt pénzintézettől, vagy köthetnek biztosítást, hiszen életkoruk önmagában magasabb kockázati faktornak számít.

- A munkahelyi diszkrimináció leginkább az ún. „fiatal időseket” érinti, sőt már a középkorosztály is veszélyeztetett (40-45 év felettiek). Jellemzően az idősebb munkavállalót érinti elsőként a leépítés, az idősebb munkakereső sokkal hosszabb ideig marad tartósan munkanélküli (Kokas \& Lakatos, 2013).

Rowe és Kahn szerint a minőségi öregedésnek 3 összetevője van, melyek a betegség alacsony valószínűsége és a betegségekkel összefüggő fogyatékosság, a magas kognitív és fizikai kapacitás, valamint aktív elkötelezettség az élet iránt. Mindhárom kifejezés relatív és külön-külön is fontosak, de ezek kombinációja képviseli a minőségi öregedést a legteljesebben (Rowe \& Kahn, 1997). Vizsgálva az egyes összetevőket, azokat további kisebb tényezőkre bonthatjuk. A betegség hiányában szerepet játszik az öröklődés, egyes genetikai tényezők és a külső környezeti tényezők, beleértve az életmód elemeit. A magas kognitív kapacitásba beletartozik az élethosszig tartó tanulás, a memória fejlesztése. Az élet iránti elkötelezettség függ az életúttól, az egyén megküzdési stratégiájától és ide sorolhatjuk a társas; családi és baráti kapcsolatokat. Vaillant és Mukamal szerint a minőségi öregedés 2 legfontosabb pszichoszociális előre jelzője a magas iskolai végzettség és a kiterjedt családi hálózat (Vaillant \& Mukamal, 2001). Az időskori jólét meghatározásához 6 funkciótartományt írnak le, melyek az orvos által értékelt objektív fizikai egészség és a visszafordíthatatlan testi fogyatékosság hiánya, a második a szubjektív egészségmegítélés, a harmadik az aktív élethossz, a negyedik terület az objektív mentális egészség. Az ötödik terület az élettel való szubjektív elégedettség és végül a hatodik a szociális támogatás. Ezeket a kategóriákat sokkal inkább kell keretként tekinteni, mintsem a minőségi öregedés meghatározó elemeinek. Teater és Chonody bemutatva a minőségi öregedés számos pontját, amelyet megfogalmaztak a szakirodalomban, felhívják a figyelmet, hogy óvatosan kell ezeket kezelni, hiszen a siker szubjektív, így sokkal inkább kell 
az emberre, mint egyénre figyelni és a szubjektív öregedés felöl megközelíteni ennek elősegítését. Nem lehet az időseket homogén csoportnak tekinteni. Továbbá fel kell ismerni a felelősséget, hogy ne támasszunk irreális elvárásokat az idősebbekkel szemben (Teater \& Chonody, 2020).

A kulturális, szociális és pszichológiai dimenziókat figyelembe véve Bengtson és munkatársai a családtagok közötti interakciót sokrétủ és többdimenziós konstrukcióként értelmezték (Bengston \& Roberts, 1991). A konstrukció elemei a következők voltak:

- Szeretet: a családtagok iránti érzelmi kötődés típusa és foka, valamint ezen érzelmek kölcsönössége (melegség, közelség, megértés, bizalom, tisztelet stb.);

- Társulás: az interakció gyakorisága és mintái, amelyek láthatók azokban a tevékenységekben, amelyekben a családtagok egymással érintkeznek, akár személyes kapcsolatba kerülés, akár a technológia révén;

- Konszenzus: az értékekben, attitűdökben és hiedelmekben való egyetértés mértéke;

- Erőforrások megosztása: a generációk közötti segítségnyújtás és az erőforrások cseréjének mintái, mint például a pénzügyi, fizikai és érzelmi támogatás;

- Családi normák: a családtagokkal szembeni egyéni kötelezettségek elvárásai, amelyek tágabb kulturális értékekkel kapcsolatosak;

- Az interakció lehetőségstruktúrája: befolyásolja a családtagok száma, típusa és földrajzi közelsége (Azevedo \& Ponte, 2020).

Összességében kijelenthető, hogy az idősödés és maga az időskor nem tekinthető homogén mintának, sokkal inkább igaz rá, hogy számtalan normális és kóros elváltozás alkotja. Nem elsősorban a naptár szerint idősödünk, és komoly különbségek észlelhetők a felmérések és vizsgálatok adatai alapján az idős egyének életminőségét befolyásoló jellemzők között (Iván, 2002).

\section{Az idősek és az infokommunikációs technológiák vonatkozásai}

Manapság, amikor egyrészt a középkorú generációk többsége már többé-kevésbé elsajátította az IKT-t a hatékony munkavégzés és szabadidős tevékenységek eszközeként, másrészt a fiatalabb lakosság számára az infokommunikációs technológiák már gyermekkoruk óta a mindennapok teljesen átlagos részévé váltak, addig az idős lakosság többségének még mindig kevés ismerete van ezen a téren (Blazun, 2013). 
Az idősebb felnőtteket gyakran sztereotip módon úgy ábrázolják, mint akik ellenállnak a változásoknak, képtelenek és nem hajlandók új technológiákat elfogadni. Úgy tünik, egyes idősebb felnőttek felvették és magukévá tették ezeket a negatív életkori sztereotípiákat és valóban túl öregnek vagy túlságosan kívülállónak tartják magukat ahhoz, hogy sikeresen alkalmazzák a mindennapi információs és kommunikációs technológiákat. Valójában a negatív öregedés önfelfogásában szenvedő idősebb felnőttek nagyobb valószínüséggel tapasztalnak fizikai, szociális vagy kognitív veszteségeket, ahogy idősödnek. Ezen kívül hajlamosak sztereotip módon cselekedni, különösen akkor, ha olyan környezetnek vannak kitéve, amely aktiválja ezeket az életkori sztereotípiákat (Köttl és mtsai, 2021). 2011-ben a hozzáférés és a hozzáférhetőség hiánya volt a két legnagyobb akadály az idősebb felnőttek és az IKT-használat között, ami tovább csökkentette a számítógépes ismereteket, hiányzott a motiváció és az új technológiák elfogadása. Egyrészt az új és feltörekvő technológiákat többnyire a fiatalabb generációk számára tervezik és forgalmazzák, akik általában a legnagyobb fogyasztói csoportot alkotják. Másrészt az idős korral járó változások, mint például a fizikai állapot általános romlása, az ízületi gyulladás és az éles látás elvesztése szintén hozzájárultak a digitális megosztottság növeléséhez.

Az idősek támogatása, különösen az otthoni gondozás sok feladatot és segítő személyt igényel. A megfelelő technológia bevezetése nagy hatással lehet a következőkre:

- mindennapi élet: háztartási tevékenységek végzésének támogatása, környezetfigyelés és lakásautomatizálás (pl. világításvezérlés);

- személyes fejlődés: tanulási tevékenységek fejlesztésének támogatásával, az egész életen át tartó tanulás fenntartása, kikapcsolódás és egyéb közösségi tevékenységek;

- speciális rehabilitációs és egészségnevelési programok kidolgozása;

- gyógyszerkezelés: e-recept, gyógyszer bevételét jelző alkalmazások;

- egészségi állapot ellenőrzése: létfontosságú jelek monitorozása (pl. vérnyomásmérés, pulzusmérés) táplálkozás és mentális funkciók figyelése;

- személyes biztonság: értesítés elesés és rutinváltás esetén (pl. hosszú ideig mozdulatlan);

- és az otthoni biztonság, beleértve a behatolás- és tüzriasztást (Teixeira és mtsai, 2011).

A negatív sztereotípiákon túllépve, képzeletben húzhatunk egy vonalat, mely elválasztja azokat az idős embereket, akik még nem használják aktívan az életükben az IKT-t azoktól, akik már igen. Egy Finnországban végzett interjúból kiderült, hogy az öregedés okozta negatív fizikai változások, mint például a szív- és tüdőbetegségek vagy a láb- és hát problémák csökkentették a saját testükbe vetett bizalmukat. Ebben a helyzetben a mobiltelefon lehetővé 
tette számukra, hogy továbbra is fenntarthassák korábbi kapcsolataikat. Ezt a lehetőséget tartotta az idősödő felnőttek számára az egyik legfontosabb kérdésnek a legtöbb interjúalany. A telefonos kommunikáció mellett sokan hasznosnak találták a szöveges üzeneteket, különösen akkor, amikor munka közben próbáltak kapcsolatba lépni gyermekeikkel. A kamera alkalmazást szórakoztatónak találták, különösen az unokák képei voltak fontosak, melyeket gyakran használták háttérképként. A telefonkönyv funkciót is hasznosnak ítélték, kivéve egy 68 éves nőt, aki fejből akarta tudni a telefonszámokat, hogy edzeni tudja a memóriáját (Suopajarvi, 2015).

\section{Az infokommunikációs technológiák elsajátitása, a tanulás folyamata}

Ahhoz, hogy mind szélesebb körben alkalmazni tudják az idősek az IKT adta lehetőségeket, az első lépést a megfelelő kompetenciák elsajátítása, vagyis a tanulás jelenti. Az idősek IKT-jártasságának növelése ma az egész életen át tartó tanulás egyik legfontosabb célja. A mai magyar társadalomban már vannak példák olyan képzésekre, amelyek céltudatosan az idősödők és idősek jellegzetes igényei szerint szerveződnek. A pozitív példák mellett is úgy gondolom, még több ilyen képzésre lenne szükség. A jelenlegi oktatási-képzési rendszer kevésbé vállal aktív szerepet az idősek tanulásában-művelődésében. Az időskorú munkavállalók 88\%-a nem találkozott gyakorlati munkája során az informatikával. A hiányos digitális kompetenciák különösen nagy problémát jelentenek a munkapiacról kiszoruló 65 év felettiek körében. A foglalkoztatás akadálya elsősorban az informatikai tudatlanság, az ekommunikáció használatából való kirekesztődés (Laukó \& Mihálka, 2016).

Az idős felnőttek jobban tanulnak olyan tanulási környezetben, amely lehetővé teszi az önálló tempójú oktatást. Ez az elv különösen érvényes azokra, akiknek meg kell tanulniuk használni az ismeretlen, modern berendezéseket. A rövidtávú memóriavesztés és a digitális technológiával kapcsolatos szorongásuk miatt nehezen emlékeznek az egyes eszközök müködtetéséhez szükséges lépésekre. Sok idős felnőtt kényelmetlenül próbálja ki magát a számítógépes környezetben és szüksége van lehetőségre, hogy megerősítse önbizalmát és önbecsülését (Henrique, 2013).

Különböző tanulmányok kimutatták, hogy az IKT attitüd összetevői módosíthatók. Az idősek IKT-műveltségének növelése érdekében a motiváció és a használat élménye nagyon fontos és kiemelt szerepe van az észlelt hasznosságnak. Sokszor ugyanis az idősek nincsenek is tisztában azzal, hogy milyen előnyt hagynak ki, addig, amíg meg nem tapasztalják és így nem is éreznek motivációt a használatra. A megfelelő szociális támogatás és a felmerülő problémák megoldásának lehetőségei tovább növelik a használati hajlandóságot (Álvarez-Dardet és mtsai, 
2020). Az idősek tekintetében gyakran alkalmazzák a kutatók a technostressz vagy technofóbia fogalmakat. Tágabb értelemben az IKT használata által elöidézett stresszt értjük alatta. (Tarafdar és mtsai, 2007). Ez a fogalom nemcsak az idősekre vonatkozik. Nimrod az idősekkel és a technostresszel kapcsolatos 2018-ban megjelent tanulmányában (Nimrod, 2018) egy új skála kifejlesztését mutatta be, amelyet a technostressz mérésére terveztek, különösen az idősebb IKT-t használók körében. A főbb stresszt előidéző állapotok a korábbi tanulmányok alapján 5 elemet tartalmaztak:

- Túlterhelés: több feladattal kell megküzdeniük, mint indokolt lenne, így végül a feladatok elvégzése is lassabb,

- Invázió: a nyilvános és személyes határok elmosódása miatt a mindennapi életbe való behatolás,

- Bonyolultság: állandó változás, az IKT használati feltételeit nehéz megtanulni és használni,

- Adatvédelem: a személyes adatok hozzáférhetősége miatti félelem,

- Befogadás: kisebbrendüség érzése a fiatalabb korosztály felhasználóihoz képest és az ebböl következő nyomás a megfelelés vonatkozásában.

Egy Németországban végzett kiscsoportos kutatás során egy társasházi lakóközösségben, a szokásos süti-és teadélutáni beszélgetés során mutattak be különböző IKT alapú lehetőségeket. A részvétel önkéntes alapú volt. A foglalkozáson táblagépeken keresztül próbálták vázolni a lehetőségeket. Kezdetben az egyszerü fotó és videókészítésével kezdték, mert az idősek egy része fényképeket hozott a családtagjairól vagy egy számukra kedves helyről. Ezután felmerült az igény, hogy ezeket a fényképeket tudják cserélni, mert az általuk készített képeken ők nem szerepelnek, viszont a többi tag által készített képeken igen. Így megtanulták az e-mail használatát, mely lehetőség során kapcsolatba kezdtek lépni a családtagjaikkal. Ezekkel az ismeretekkel interakcióba tudtak lépni a szomszédjaikkal, így a szociális életükre is hatással volt, új kapcsolatokat alakítottak ki. Majd további igényként felmerült a távoli rokonokkal való kapcsolattartás, nem csak írás formájában, így ismerkedtek meg a Skype-pal. Az élménybeszámoló hatására a csoport többi résztvevője is letöltötte és használni kezdte az alkalmazást. Később egymás között osztották meg a nyaralási képeket és tapasztalatokat, amíg nem tudtak részt venni a csoportos órákon. A foglalkozás során a Google Maps segítségével virtuális séta keretében bemutatták a szülőfalujukat, korábbi iskoláikat. Ezek a kiscsoportos kutatások megmutatták, hogy mennyire fontos az idős embereknek a visszaemlékezés és a személyes életút bemutatása (Müller és mtsai, 2015). 


\section{A magányosság perspektívái}

A társadalmi elszigeteltség és a magány különösen káros hatással van az idősek testi és lelki egészségére. Ez az idősek körülbelül 30-50\%-t érinti. A magány érzéséhez kapcsolódó társadalmi elszigeteltség tudata és az ebből fakadó erősödő hiányérzet ritkább interakciókhoz vezet. Továbbá a korlátozott közösségi hálózatokhoz kapcsolódó szociális és családi támogatás jelentősen erősítheti az affektív (érzelmi alapú) rendellenességeket, amelyek elősegítik vagy súlyosbítják a szorongás és a depresszió tüneteit (Tanner és mtsai, 2014). Egyes tanulmányok szerint a szubjektív szociális elszigeteltség (magányosság) szignifikánsan nagyobb mértékben járul hozzá a depresszió és az alvászavarok tüneteihez, mint az objektív társadalmi elszigeteltség (Doménech-Abella és mtsai, 2019; Choi és mtsai, 2015). Kutatók felismerték, hogy idős pesszimista önértékelésü embereknél, illetve gyakran depressziós vagy érzelmi problémákkal küzdő személyeknél nagyobb a halálozási kockázat. Míg az idős emberek, akik élvezik az életüket, általában jobb egészségi állapotot tapasztalnak (Liorenti-Barosso és mtsai, 2021).

A népesség elöregedésével párhuzamosan jelentős változások történtek az úgynevezett posztmodern család környezetében, amelyet annak strukturális törékenysége jellemez. Ezek a változások bizonytalanságot keltenek a társadalmi kapcsolatokban, és befolyásolják az élet során bekövetkező átmenetek szerepét, új kihívások elé állítva az egyéneket, a családokat és társadalmi életüket (Bobillier-Chaumon és mtsai, 2014). Bár a magány magában foglalhatja az objektív társadalmi kapcsolatok hiányát is, a társadalmi elszigetelődést a valódi és a kívánt kapcsolatok közötti eltérés szubjektív észleléseként fogalmazták meg. Az érzelmi elszigeteltség a kapcsolatok minőségére utal, ami a széthúzás érzését, az intimitás hiányát vagy a jelentős kapcsolatok elvesztését jelenti. Az érzelmi magányt az „abszolút magány” egyik legmélyebb és lehengerlőbb érzésének tekintik. Az öregséggel kapcsolatos érzelmi problémák gyakran összefüggnek a stresszes események tapasztalataival, amelyek gyakoriak. Az ilyen érzelmi helyzetek szomorúsággal, tehetetlenséggel, magányossággal járnak, és tükrözhetik a társas és személyes veszteségek kezelésének egyéni tapasztalatait, amelyek például a családtagok elvesztéséből származhatnak (Azevedo \& Ponte, 2020). Azevedo és Ponte rámutat arra is, hogy a technológia által közvetített generációk közötti kapcsolatokat nemcsak az affinitás és az idősek családban betöltött szerepével kapcsolatos közös értékek motiválják, hanem a fiatalok irányából érzékelt nyomás is.

Amikor a fiatal felnőttek idősödő szüleiket meglátogatják, a kölcsönös segítségnyújtás bizonyos erőforrások cseréjén alapulhat. Az idő előrehaladtával ugyanakkor a generációk 
közötti különbségek a felhalmozódó tapasztalatok különbségeinek növekedése miatt szélesedhetnek, ez pedig egyre nehezebbé teszi a segítség biztosítását.

Egyes résztvevőknél nem merül fel a családtagok önkéntes támogatásának elvárása az IKT használatában. A fiatalabb generációk bizonyos esetekben segíthetnek, mert erkölcsi kötelességüknek érzik, és nem azért, mert a digitális technológia segítségével minőségi kapcsolatokat szeretnének kialakítani szüleikkel és nagyszüleikkel. Segíthetnek, de a generációk közötti szolidaritás koncepciója által javasolt közelség és csere nélkül. Korábbi tanulmányok szerint az idősek számára tervezett IKT-beavatkozások hatékonyan csökkentik a társadalmi elszigeteltséget és a magányt, azáltal, hogy elősegítik a társadalmi kommunikációt és javítják a fizikai tevékenységekben való részvételt az idősek körében (Choi \& Lee, 2021).

A magányosság érzése csökkenthető internet alapú közösségi terekben, akár virtuális világokban történő barangolás segítségével is. További kihívás lehet a virtuális világok megismerése, például a Second Life három dimenziós terének feltérképezésével. Nemcsak fiatalok vagy középkorúak számára áll fenn ez a lehetőség, az időskorúaknak is számos felfedezhető területet tartogat a Second Life. Ez a virtuális tér olyan világ, mely egyfajta közösségi hálózatként funkcionál, ahol a világba belépett személyek közösen hozhatnak létre és szerkeszthetnek objektumokat, az egymással való találkozáson, beszélgetésen és a meglévő tárgyakkal való interakciók kivitelezésén kívül (Kristóf és mtsai, 2011).

Meg kell jegyeznünk ugyanakkor, hogy új, kevéssé hozzáértő, a digitális kompetenciákban járatlan felhasználók esetén mindenképp javasolt a virtuális tér alapfunkcióinak, moduljainak bemutatása vagy valamilyen valós időben történő kapcsolattartás, vagy egy, a Second Life terében elhelyezhető oktatóanyag segítségével, mivel számukra a környezet használata kezdetben nehézkes lehet. Érdemes ugyanakkor ezen felhasználók számára, illetve az idősek részére is biztosítani a három dimenziós tér alkalmazásának lehetőségét. Kiderült ugyanis, hogy a virtuális terek megfelelő használatában még járatlan személyek is szívesen használták a Second Life terét, izgalmasnak találták a lehetőségeket, és motiválta őket az a tény, hogy az alapvetőbb tevékenységek elsajátíthatók voltak kevés gyakorlás után is (Kristóf \& Tóth, 2019).

\section{Az egészséggel kapcsolatos lehetöségek}

Az idősek arányának a népességen belüli növekedése az egészségügyi ellátás költségeinek emelkedését okozza. Az otthoni betegápolás és a szociális gondozás egy idősödő társadalomban egyre erősebben fonódik össze. A fentiek megfelelő fenntartása már nemcsak 
egészségügyi, hanem önkormányzati feladat is, így pedig a piaci alapon müködtetett ellátógondozó létesítmények száma megnövekedhet (Paulikné Varga, 2020a).

Önmagában az, hogy tovább élünk, nem jelent fejlődést, ha ezek az évek nem egészségesen telnek. Valójában, a krónikus betegségek, mint a krónikus szív- és érrendszeri betegségek, cukorbetegség, csontritkulás, neurodegeneratív betegségek, a krónikus légzési rendellenességek, a demencia és egyéb kóros állapotok fokozódnak az idősödő lakosság körében. Ezen súlyosbító tényezők együttes megjelenésével együtt a fizikai és kognitív képességek általánosan romolhatnak. Fokozott kockázattal érhetik az időseket az esések, törések, fogyatékosságok, a táplálkozás romlása, neurológiai és cerebrovaszkuláris rendellenességek vagy a súlyos zavartság szindróma (Csesznek és mtsai, 2020).

Jelenleg is létezik már az egészségügyi ipar, melynek kialakulását sok egyéb tényező mellett a gyógyszeripar erőteljes ütemü fejlődésének és fejlesztésének, az internet világméretü hatásainak, a digitális adatbázisok esszenciális fontosságának és a képalkotó diagnosztikai technikák elterjedésének köszönhetünk (Paulikné Varga, 2020b).

A fenti tények az egészséggel kapcsolatos információs és kommunikációs technológiák (IKT) bevezetését teszik szükségessé, hogy az időseknek költséghatékonyabbá válhasson az egészségügyi ellátása. Mindehhez viszont az idősebb felnőtteknek fel kell készülniük e technológiák alkalmazására (Heart \& Kalderon, 2013).

Az IKT alapú technológiák hozzáadott értéket is jelenthetnek számos olyan klinikai paraméter értékelésekor és nyomon követésekor, amelyekkel kapcsolatban a szakértők gyakran jelentenek értékelési torzításokat. Ez különösen igaz a neuropszichiátriai tünetekre, amelyek esetében a következő veszélyek állhatnak fenn:

- hiányzik az aktuális értékelési kérdőívek és interjúk objektivitása,

- a páciens önbevallásaihoz szubjektivitás kapcsolódik,

- az értékelő szubjektív,

- kulturális különbségek lehetnek a tünetek kifejezőképességében

- kognitív károsodás miatti agnózia, észlelési rendellenesség, felismerési képtelenség lehet jelen,

- fennállhat a neuropszichiátriai tünetek miatti rendellenességek tudatosságának hiánya (Auriane és mtsai, 2016).

Az IKT-s megoldások használatával lehetővé tudják tenni a betegek teljesítményének és cselekvéseinek valós idejü és valós élethelyzetekben történő megfigyelését és pontos értékelését. Az IKT-módszerek, ha a beteg kívánt funkcionális eredményeire összpontosítanak, 
klinikailag relevánsabb információkat szolgáltathatnak a kezelésre adott teljes válasz meghatározásához, valamint a demencia pontos diagnosztizálásához. Ezen túlmenően, az ilyen módszerekkel azonosíthatók azok a váratlan változások, amelyeket a hagyományos pszichometriai mérések nem képesek detektálni (Robert és mtsai., 2013).

Számos olyan eszköz van, melyeknek a belsejében elhelyezett érzékelők figyelik az egyedül élő időseket otthonukban, az általuk gyűjtött adatoknak köszönhetően riaszthatnak gondozókat, rokonokat, ha szükséges. Ezek az érzékelők lehetővé teszik az idősek viselkedésének megfigyelését. Monitorozható, hogy hányszor nyitja ki egy cukorbeteg a hütőszekrényt, hogy egy idős ember milyen mozdulatokat végez a házban, hányszor használja a konyhát, megfelelően használja-e és így tovább.

Az I-DONT-FALL projekt célja az esés észlelési és kockázatkezelési keretrendszerének megvalósítása a kockázatértékelés többtényezős megközelítésével. A páciens esésérzékelőt visel, amely, ha eséseseményt észlel, riasztást ad ki Bluetooth kapcsolaton keresztül egy Android eszközre. Az Android eszköz automatikus üzeneteket küld az eseményről egy címzettlistára. Figyelmezteti a telefonos szolgálatot is, mely során közvetlenül felveszik a kapcsolatot az idős személlyel vagy a gondozójával, hogy ellenőrizzék állapotát, illetve szükség esetén kapcsolatba lépnek a klinikai sürgősségi személyzettel (Genovese és mtsai, 2018).

Egészségi monitorozást tesznek lehetővé különféle okoskarkötők is. Ezek képesek észlelni olyan adatokat, mint a vérnyomás és pulzusszám, rögzíteni tudják a gyaloglás lépésszámát, az alvás minőségét. Egy kutatás során a karkötők óránként rögzítették a páciens vérnyomás- és pulzusszámadatait; az adatokat mobilalkalmazáson rögzítették. A vérnyomást és a pulzusszámot automatikusan átlagolták naponta. A lépések számát ebben a vizsgálatban naponta 0 óra és 20 óra között számolták. A hordható készülék beépített testmozgásrögzítője az alvás közbeni csuklómozgások amplitúdója és gyakorisága szerint mérte az alvás minőségét. A hordható eszköz a pulzushullámalakot, a pulzushullám emelkedő meredekségét és a sávidőt egy fotoelektromos érzékelő segítségével becsülte meg. A hordható eszköz zöld fénykibocsátó dióda (LED) fényét egy fotodiódával párosították, hogy megvilágítsák a csukló bőr alatti ereit. A vörös fényt visszaverő és zöld fényt elnyelő megoldáson keresztül a hordható eszközök mérik a véráramlást és kiszámítják a pulzusszámot. A hordható eszköz használatakor az idősek az alkalmazás kijelzőjén keresztül láthatták saját egészségi adataikat. Személyes célokat is kitűzhettek, ezzel is növelve a részvételi kedvet.

Egy tanulmány kimutatta, hogy a séta csökkentheti a szív- és érrendszeri betegségek kockázatát és javíthatja az idősek egészségét (Klenk és mtsai, 2013). Ez előmozdítja az idősek 
egészségügyi kezelésének fontosságát. A séta az idősek leggyakoribb gyakorlata, ezért személyes egészségi adataik szerves részét képezi a megtett lépések számának rögzítése. A jövőben az idősek egészségi állapota más egészségi adatokkal együtt értékelhető az egészséget befolyásoló tényezők meghatározásakor (Zhou és mtsai, 2019).

Ezek az eszközök külön-külön, egyedi eredményekre összpontosítanak. A magas vérnyomás monitorozására szolgáló öngondoskodó alkalmazások gyakran egyedi jeleket/tüneteket értékelnek, mint a vérnyomás vagy az életmódbeli viselkedés, a fogyás vagy a dohányzás abbahagyása. Mindazonáltal több érték együttes jelenléte klinikailag releváns különösen multimorbiditás esetén. Mivel a magas vérnyomás tünete lehet egy másik mögöttes megbetegedésnek, például veseartéria-szűkületnek, veseelégtelenségnek, metabolikus szindrómának, az érintett személynek több jelet és tünetet is követnie kell. Hasznos lehet például az IKT használata a vércukorszint, a testsúly, a vérzsír (trigliceridszint és a nagy sürüségü lipoproteinszint) egyidejü nyomon követésére olyan embereknél, akik metabolikus szindrómával összefüggő magas vérnyomásban szenvednek (Monaco és mtsai, 2019).

Úgy tünik, hogy az álmatlanság (insomnia) rokkantsággal, sérülési kockázattal, metabolikus szindrómával, szív- és érrendszeri betegségek kockázatával, kognitív károsodással, depresszióval és életminőség romlásával függ össze (Salvemini és mtsai, 2019). A legtöbb kezelési iránymutatás azt javasolja, hogy az álmatlanság szabályozásának nem gyógyszeres megközelítései, beleértve az alváshigiéniát és a viselkedési módszereket, használhatók támogató terápiaként. Ezek közül az insomnia kognitív viselkedésterápiájának erős tapasztalati bizonyítékai vannak. Egy internet-alapú program hasznos és olcsó első lépésnek bizonyult az álmatlanság kezelésében. Salvemini és munkatársai rámutattak, hogy randomizált, kontrollált vizsgálatokra alapozva jelentős bizonyíték áll rendelkezésre arra vonatkozóan, hogy a kognitív viselkedésterápia hatékony és hosszú távú kezelés a betegek 5070\%-ánál. A terápia kiszüri azokat a tényezőket, amelyek idővel fenntartják az álmatlanságot, beleértve az álmatlanságot állandósító szokásokat, az alvással kapcsolatos diszfunkcionális felismeréseket és a homeosztatikus alvási késztetés károsodását. Nagyon fontos az alvásnaplók rögzítése és olvasása. Egy 31 fővel végzett interjús kutatás során összegezve az eredményeiket, a kutatók arra a következtetésre jutottak, hogy az IKT-alapú gondozói támogatás a vidéki területeken élő idősek számára egy módja annak, hogy megtanulják az új technológia átvételét és visszanyerjék a társadalmi befogadást. Ez a mindennapi élet minőségének javításához is hozzájárul (Blusi és mtsai, 2013). 


\section{Összefoglalás}

Az IKT számtalan területen próbál eszközként megjelenni az idősek életében. Azért érdekes kutatási terület, mert gyakran, akik kutatják sem tudják, milyen élethelyzeteket hoz az időskor, mik azok a tényezők, azok a sajátosságok, amiket csak elmondhatnak az idősek, de a társadalom többi szereplője nem tudja megélni és megérteni. Az idősek IKT befogadásával kapcsolatban leglényegesebbnek az észlelt hasznosság, valamint a családi és baráti kapcsolatok megléte és támogató jelenléte bizonyult. Így bármilyen technológiai eszköz és fejlesztés csak akkor képes hozzáadott értéket adni, ha az idősek tudják azt a saját életükben alkalmazni. Számos cikk hívta fel a figyelmet arra a gyengeségre, amelyek az eszközök fogyasztóközönségét érintik. A legtöbb eszköz föleg a fiataloknak, illetve a középosztálynak szól, az idősekre nem fordítanak kellő figyelmet ebből a szempontból. Fogyasztó társadalom lévén ennek megváltoztatása csak szoros összefogással lehetséges. Fel kell ismernünk a felelősséget az idősebb családtagjainkkal, rokonainkkal szemben, aktívan kell részt vállalni a támogatásukban. Ez a változás érinti a gyártókat, az egészségügyben dolgozókat, a családtagokat, az oktatási rendszert. Az idősek általában azt fejezték ki, hogy szeretnének tanulni és használni az IKT eszközöket, de ennek több korlátja is van. Az idős résztvevők közül szinte mindegyik hangsúlyozta, hogy nem akar kiszorulni a társadalomból. Általában a gyermekeikkel és fiatalabbakkal való kapcsolat és kommunikáció hiányára panaszkodtak. Az infokommunikációs technológiák hatékony eszközként funkcionálhatnak az idős polgárok társadalomba való visszailleszkedésére, széles körü tapasztalataik hasznosítására és az egészséges időskor biztosítására. Az egyik legnagyobb kihívás az, hogy a piacon jelenleg sok IKT alapú megoldást nem a célcsoporttal együtt fejlesztettek ki. Alapvető fontosságú, hogy ezek a technológiák figyelembe vegyék az idősek szükségleteit, képességeit, erőforrásait és idejét. Valójában az IKT-hoz való hozzáférés az idősebb lakosság körében különböző tényezőktől függően változhat, például az oktatástól, a társadalmi-gazdasági helyzettől, sőt a technológia használatára való képességüktől és hajlandóságuktól is. Az IKT alapú technológiák nem mindig integrálódnak megfelelően a mindennapi tevékenységek természetes folyamatába klinikai vagy otthoni környezetben, ami fontos az ilyen technológiák hosszú távú fenntarthatóságának eléréséhez. Ezért elengedhetetlen, hogy a megcélzott felhasználók, azaz az idős emberek, részesei legyenek az alkotási folyamatnak. A közös alkotás a befogadást is megkönnyítheti azáltal, hogy az idős embereket, valamint a szolgáltatókat is bevonják az IKThasználathoz szükséges oktatás és képzés tervezésébe. Szélesebb körben kell terjeszteni azt a pozitív képet, hogy az időskor nem jár együtt a társadalmi elszigeteltséggel. A magányosság 
csökkentésében jelentős szerepet játszik az IKT, ezáltal nő az életminőség mely befolyásolja az egészségünket is. Ezen kívül az egészségügyi gondozást is jelentősen megkönnyíti, kizárva a korlátokat, a szubjektivitásból adódó torzításokat. Segítségül szolgál a biztonságos közlekedéshez, a személyi és otthoni biztonsághoz. Azok az idős személyek, akik már alkalmazzák az élet valamely területén az IKT-t, pozitívan értékelik és hajlandók a tartós használatukra.

\section{Irodalomjegyzék}

Al-Rahmi, W. M., Alzahrani, A. I., Yahaya, N., Alalwan, N., \& Kamin, Y. B. (2020). Digital communication: Information and communication technology (ICT) usage for education sustainability. Sustainability, 12(12), 5052.

Álvarez-Dardet, S. M., Lara, B. L., \& Pérez-Padilla, J. (2020). Older adults and ICT adoption: Analysis of the use and attitudes toward computers in elderly Spanish people. Computers in Human Behavior(110), 1-8.

Azevedo, C., \& Ponte, C. (2020). Intergenerational solidarity or intergenerational gap? How elderly people experience ICT within their family context. Observatorio, 14(3), 16-35.

Auriane, G., David, B., Valeria, M., Roxane, F., Anne-Marie, Z. C., Susanne, T., Renaud, D. (2016). Recommendations for the Use of ICT in Elderly Populations with Affective Disorders. Frontiers in Aging Neuroscience, 8, 269.

Balázs, K., \& Bene, Á. (2019). Az aktív időskor szerepe a fogyasztóvédelemben. Magyar Gerontológia, 11(37-38), 65-77.

Bene, Á., Móré, M., \& Zombory, J. (2020). A digitalizáció néhány elemének időseket érintő hatásai - karantén előtti helyzetkép. Magyar Gerontológia, 12(39), 29-51.

Bengston, V. L., \& Roberts, R. E. (1991). Intergenerational solidarity in aging families: An example of formal theory construction. Journal of Marriage and the Family, 53(4), 856-870.

Blazun, H. (2013). Elderly People's Quality of Life with Information and Communication Technology (ICT): Toward a Model of Adaptation to ICT in Old Age. Juvenes Print Oy.

Blusi, M., Asplund, K., \& Jong, M. (2013). Older family carers in rural areas: experiences from using caregiver support services based on Information and Communication Technology (ICT). European Journal of Ageing, 10(3), 191-199. 
Bobillier-Chaumon, M. E., Michel, C., Tarpin-Bernard, F., \& Croisile, B. (2014). Can ICT improve the quality of life of elderly adults living in residential home care units? From actual impacts to hidden artefacts. Behaviour and Information Technology, 33(6), 574.

Choi, H., Irwin, M. R., \& Cho, H. J. (2015). Impact of social isolation on behavioral health in elderly: Systematic review. World J Psychiatry, 5(4), 432-438.

Choi, K. H., \& Lee, H. S. (2021). Trends and Effectiveness of ICT Interventions for the Elderly to Reduce Loneliness: A Systematic Review. Healthcare, 9(3), 293.

Csesznek, K., Cersosimo, G., \& Landolfi, L. (2020). New challenges for the elderly. A sociological reflection on socialization to ICT's as an oppurtunity in the time of COVid-19. Revista română de sociologie, 31(1-2), 49-58.

Doménech-Abella, J., Mundó, J., Haro, J. M., \& Rubio-Valera, M. (2019). Anxiety, depression, loneliness and social network in the elderly: Longitudinal associations from The Irish Longitudinal Study on Ageing (TILDA). Journal of Affective Disorders, 246, 82-88.

Fehérvári, A. (2017). Digitális egyenlőtlenségek Magyarországon. Educatio, 26(2), 157-168.

Genovese, V., Mannini, A., Guaitolini, M., \& Sabatini, A. M. (2018). Wearable Inertial Sensing for ICT Management of Fall Detection, Fall Prevention, and Assessment in Elderly. Technologies, 6(4), 91.

Giddens, A. (2008). Szociológia. Osiris Kiadó.

Heart, T., \& Kalderon, E. (2013). Older adults: Are they ready to adopt health-related ICT? International journal of medical informatics, 82(11), 209-231.

Henrique, G. (2013). Elderly \& ICT: a need and urgency for an effective info-inclusion. Imprensa da Universidade de Coimbra, 211-230.

Huszti, É., Bene, Á., \& Patyán, L. (2020). Időskorúak a karantén helyzetben. Magyar Gerontológia, 12(Különszám), 32-33.

Iván, L. (2002). Az öregedés aktuális kérdései. Magyar Tudomány, 2002(4), 412-418.

Klenk, J., Denkinger, M., Nikolaus, T., Peter, R., Rothenbacher, D., \& Koenig, W. (2013). Association of objectively measured physical activity with established and novel cardiovascular biomarkers in elderly subjects: every step counts. Epidemiol Community Health, 67, 194-197. 
Kokas, D., \& Lakatos, S. (2013). Az idősek. In A. Varga (Ed.), Esélyegyenlõség a mai Magyarországon (pp. 163-172). Pécs, HU: Pécsi Tudományegyetem BTK NTI Romológia és Nevelésszociológia Tanszék.

Köttl, H., Cohn-Schwartz, E., \& Ayalon, L. (2021). Self-Perceptions of Aging and Everyday ICT Engagement: A Test of Reciprocal Associations. The Journals of Gerontology: Series B, 76(9), 1913-1922.

Kristóf, Z. (2020). International trends of remote teaching ordered in light of the coronavirus (COVID-19) and its most popular video conferencing applications that implement communication. Central European Journal of Educational Research, 2(2), 84-92.

Kristóf, Z., Bodnár, K., \& Takács, P. (2011). Implementation opportunities of the Moodle Learning Management System in virtual environment: The Sloodle Project. Teaching Mathematics and Computer Science, 9(2), 275-293.

Kristóf, Z., \& Tóth, K. (2019). Developing and examining a virtual learning environment. Hungarian Educational Research Journal, 9(3), 511-526.

Laukó, G., \& Mihálka, M. (2016). Az időskorúak társadalmi esélyegyenlősége. Magyar Gerontológia, 8(29-30), 72-100.

Liorenti-Barosso, C., Kolotouchkina, O., \& Manas-Viniegra, L. (2021). The Enabling Role of ICT to Mitigate the Negative Effects of Emotional and Social Loneliness of the Elderly during COVID-19 Pandemic. Int. J. Environ. Res. Public Health, 18(8), 3923.

Molnár, G. (2011). Az információs-kommunikációs technológiák hatása a tanulásra és oktatásra. Magyar tudomány, 172(9), 1038-1047.

Monaco, A., Maggi, S., Cola, P. D., Hassan, T. A., Palmer, K., \& Donde, S. (2019). Information and communication technology for increasing healthy ageing in people with noncommunicable diseases: identifying challenges and further areas for development. Aging Clinical and Experimental Research volume, 31, 1689-1693.

Müller, C., Hornung, D., Hamm, T., \& Wulf, V. (2015). Measures and tools for supporting ICT appropriation by elderly and non tech-savvy persons in a long-term perspective. In ECSCW 2015: Proceedings of the 14th European Conference on Computer Supported Cooperative Work (263-281). Oslo, Norway.

Nimrod, G. (2018). Technostress: measuring a new threat to well-being in later life. Aging \& Menthal Health, 22(8), 1086-1093. 
Paulikné Varga, B. (2020a). Néhány szempont a magyar egészségügyi ágazat pro blématérképének összeállításához. Acta Medicinae et Sociologica, 11(30), 23-31.

Paulikné Varga, B. (2020b). Kutatási kérdőjelek az egészségügyi szervezetfejlesztsének vizsgálatában. Acta Medicinae et Sociologica, 11(31), 144-163.

Peterson, C. B., \& Prasad, N. R. (2011). Easy life, intelligent systems, and life 2.0: European research on ict for aging adults. In IASTED HCI Conference 2011. ACTA Press.

Prensky, M. (2001). Digital natives, digital immigrants part 2: Do they really think differently? On the Horizon, 9.(6), 1-6.

Prensky, M. (2009). H. Sapiens Digital: From Digital Immigrants and Digital Natives to Digital Wisdom. Journal of Online Education, 5(3), 1552-3233.

R. Fedor, A., Ungvári, S., \& Markos, V. (2021). Az idősek szociális kapcsolatai és szabadidőeltöltése. Metszetek, 10(1), 86-104.

Robert, P., Castelli, E., Chung, P. C., Crispim, C., Mallea, P., \& Bremond, F. (2013). SWEETHOME ICT technologies for the assessment of elderly subjects. Innovation and Research in BioMedical engineering, 34(2), 186-190.

Rowe, J. W., \& Kahn, L. R. (1997). Succesful Aging. The Gerontologist, 37(4), 433-440.

Salvemini, A., D'onofrio, G., Ciccone, F., Greco, A., Tullio, A., Addante, F., Greco, A. (2019). Insomnia and Information and Communication Technologies (ICT) in Elderly People: A Systematic Review. Medical Sciences, 7(6), 70.

Suopajarvi, T. (2015). Past experiences, current practices and future design: Ethnographic study of aging adults' everyday ICT practices - And how it could benefit public ubiquitous computing design. Technological Forecasting and Social Change, 93, 112-123.

Takács, P., \& Fábián, G. (2014). A nyíregyházi lakossági panelfelméréshez kapcsolódó életminőség vizsgálatok. Acta Medicinae et Sociologica, 5(12-13), 165-188.

Tanner, E. K., Martinez, I. L., \& Harris, M. (2014). Examining functional and social determinants of depression in community-dwelling older adults: Implications for practice. Geriatric Nursing, 35(3), 236-240.

Tarafdar, M., Tu, Q., Ragu-Nathan, B. S., \& Ragu-Nathan, T. (2007). The Impact of Technostress on Role Stress and Productivity. Journal of Management Information Systems, 24(1), 301-328. 
Teater, B., \& Chonody, J. M. (2020). How Do Older Adults Define Successful Aging? A Scoping Review. The International Journal of Aging and Human Development, 91(4), 599625 .

Teixeira, A., Rocha, N., Dias, M. S., Braga, D., Queirós, A., Pacheco, O., Pereira, C. (2011). A New Living Lab for Usability Evaluation of ICT and Next Generation Networks for Elderly@ Home. In Proceedings of the 1st International Living Usability Lab Workshop on AAL Latest Solutions, Trends and Applications (AAL-2011), 85-97.

Vaillant, G. E., \& Mukamal, K. (2001). Successful Aging. American Journal of Psychiatry, $158(6), 839-847$.

Z. Karvalics, L. (2001). Bevezető az információs társadalom tudománytörténetéhez. Információs társadalom, 1(1), 34-48.

Zhou, S., Ogihara, A., Nishimura, S., \& Jin, Q. (2019). Analysis of health changes and the association of health indicators in the elderly using TCM pulse diagnosis assisted with ICT devices: A time series study. European Journal of Integrative Medicine, 27, 105-113.

\section{A szerzők:}

\section{Kristóf Zsolt ${ }^{1}$, Győri Anita ${ }^{2}$}

${ }^{1}$ Adjunktus, Debreceni Egyetem Egészségügyi Kar, Egészségügyi Informatikai Tanszék, PhD-hallgató, Debreceni Egyetem Humán Tudományok Doktori Iskola

${ }^{2}$ Végzős egészségügyi szervező, Debreceni Egyetem, Egészségügyi Kar

\section{Levelező szerző elérhetősége:}

\section{Kristóf Zsolt}

Debreceni Egyetem Egészségügyi Kar, Egészségügyi Informatikai Tanszék, PhD-hallgató, Debreceni Egyetem Humán Tudományok Doktori Iskola e-mail: kristof.zsolt@foh.unideb.hu 